\title{
Discussion Paper No. 2002/124
}

\section{Building Institutions in Post-Conflict African Economies}

\author{
Janine Aron*
}

December 2002

\begin{abstract}
Institutions are altered by conflict, depending on the scale, duration and type of war. At one extreme, formal political, social and economic institutions may be completely destroyed (e.g. Somalia), while the importance and type of informal institutions may be changed. This survey addresses some of the current issues in the design and implementation of institutional building and reform in developing countries, and highlights the particular difficulties faced by post-conflict countries. However, research on practical policy interventions toward institution-building is still at an early stage.
\end{abstract}

Keywords: institutions, reconstruction, reform

JEL classification: K00, O17, O19, O55

Copyright (C) UNU/WIDER 2002

* Centre for the Study of African Economies, Department of Economics, University of Oxford

This study has been prepared within the UNU/WIDER project on Underdevelopment, Transition, and Reconstruction in Sub-Saharan Africa which is directed by Dr Tony Addison.

UNU/WIDER gratefully acknowledges the financial contribution to the project by the Government of Italy (Directorate General for Development Cooperation), the Government of Sweden (Swedish International Development Cooperation Agency), and the Government of the United Kingdom (Department for International Development). These agencies are not responsible for any information provided or views expressed, which remain those of the authors alone. 


\section{Acknowledgements}

I am very grateful to the following people for their comments: Tony Addison, Abigail Barr, Steven Friedman, Joshua Getzler, John Muellbauer, Frances Stewart, John Toye, and an anonymous referee.

UNU World Institute for Development Economics Research (UNU/WIDER) was established by the United Nations University as its first research and training centre and started work in Helsinki, Finland in 1985. The purpose of the Institute is to undertake applied research and policy analysis on structural changes affecting the developing and transitional economies, to provide a forum for the advocacy of policies leading to robust, equitable and environmentally sustainable growth, and to promote capacity strengthening and training in the field of economic and social policy making. Its work is carried out by staff researchers and visiting scholars in Helsinki and through networks of collaborating scholars and institutions around the world.

UNU World Institute for Development Economics Research (UNU/WIDER)

Katajanokanlaituri 6 B, 00160 Helsinki, Finland

Camera-ready typescript prepared by Liisa Roponen at UNU/WIDER

Printed at UNU/WIDER, Helsinki

The views expressed in this publication are those of the author(s). Publication does not imply endorsement by the Institute or the United Nations University, nor by the programme/project sponsors, of any of the views expressed.

ISSN 1609-5774

ISBN 92-9190-374-4 (printed publication)

ISBN 92-9190-375-2 (internet publication) 


\section{The re-emphasis on institutions and institutional change in the 1990s}

Disappointing growth in reforming African economies, despite extensive price- and market-related reforms from the 1980s onward, has refocused attention on the role of effective state and private institutions in promoting investment and growth. This survey addresses some of the current issues in the design and implementation of institutional reform, and highlights the particular difficulties faced by 'post-conflict' countries.

The definition of 'institutions' itself has been the subject of recent contention, but has come to be dominated by the North framework (e.g. North 1990 and 1997). By institutions, therefore, we mean the 'rules of the game', or both the formal and informal constraints on political, economic and social activities (the North framework and the link to economic growth are discussed below). Important questions concern how appropriate these rules are, whether they can be reliably enforced, and how malleable organizations are if institutional change is desirable. Prominent economic examples include the protection of property and contract rights.

The de-emphasis of institutions in the World Bank's economic reforms in developing countries during the 1970s and 1980s is documented by Clement and Murrell (1999). In general, aid donors concluded that the African state was corrupt and accordingly they encouraged a reduced role for the state, substituting private sector activity wherever possible in the first-generation of reforms. This narrowing of the scope for government compounded the 'withering away of the state', already evident in the flourishing of parallel markets after decades of misguided macroeconomic policies (Kiguel et al. 1997). However, adequate regulatory capacity was not put in place to supervise, in the public interest, newly liberalized markets and private sector activity (Collier and Gunning 1999; Collier 1996). The neglect by the 'Washington consensus' of appropriate institutional design was particularly evident in the financial sector, for as Stiglitz concludes: 'all too often the dogma of liberalization became an end in itself, not a means of achieving a better financial system' (Stiglitz 1998: 16). The legacy for the 1990s and beyond was African states with considerably weakened institutional capacity (Aron 1996).

In recent years there has been a notable volte-face amongst the multilateral agencies. Now they actively promote the role of institutions to protect property rights and contract, and encourage civil society and good governance (e.g. World Bank 1994, 1997 and 2002). The new emphasis on institutions arises partly from their market- and institution-building experiences in the transition economies of East Europe and the former Soviet Union (FSU) countries after 1989. It was reinforced by the emerging market currency and banking crises of 1997-98, given the role played by rapid financial liberalization without adequate supervisory structures and prudential regulation, and less than transparent political governance.

Institutional explanations of low investment and poor export response in African economies also centre on the perceptions of investors. In the more globalized economic environment of the 1990s, many African countries liberalized trade and partly liberalized capital accounts. Private sector investment or risk ratings have achieved prominence in influencing the net flows of international private capital to these countries. Ratings comprise weighted indexes reflecting both a country's macroeconomic and financial performance and prospects, and subjective assessments of 
institutional factors such as the degree of bureaucratic delays, corruption, respect of property and contract enforceability (see Aron 2000: Table 1).

A long tradition of microeconomic research on economic activity in poor countries where formal rules are weak and poorly enforced, has lately received a strong reemphasis under the terms social capital, trust and networks (surveyed in Woolcock and Narayan 2000; Gambetta 1988). Many case studies indicate that even where informal economic activity is extensive, informal institutions may achieve only limited contract and property rights. Without formal institutions, transformation costs and transactions costs of exchange are significantly raised (e.g. Fafchamps 1996; Fafchamps and Minten 2001). The lack of an effective legal framework may help perpetuate poverty in poor countries.

Moreover, a burgeoning cross-country literature has tried to establish a causal link between diverse empirical measures of political, social and economic institutions and aggregate real growth. Unfortunately, the theoretical basis of this research (the extended Solow growth model: Mankiw et al. 1992) was until recently divorced from the large pre-existing literature on institutions (e.g. the highly influential work of North (1990), and his school). This created confusion in the literature, and at times strong and unjustifiable claims for the influence of institutions on growth. Nevertheless, on balance, the evidence is probably supportive of a role for institutions in promoting growth (survey in Aron 2000).

In practice, little is known about the sustainable implementation of legal and other institutional reforms in poor countries. The 'new institutional economics' is essentially prescriptive, with suggestions for improved incentive structures and organizations within classes of contracts (given monitoring costs and asymmetric information) expected to result in greater institutional efficiency. Issues of implementation are not addressed. Nor is the glossing over such difficulties of recent vintage. The New Development Economics school drew attention to market failure in the 1970s and 1980s: but in prescribing complex state interventions, it effectively bypassed questions of the ubiquitous failure of government implementation in poor countries (Stiglitz 1994 and 1986).

That economists often take an optimistic view on institutional change, may be linked to the lack of an explicit treatment of institutions in theoretical models. Organizations have been viewed as highly malleable and thus able to respond rapidly to changed incentives. By contrast, most institutionalists hold that institutional change is path-dependent and incremental, and highly circumscribed by a reluctance within existing organizations to alter long-entrenched practices and norms (David 1994). David's is a functional analysis, the important contribution of which is to focus attention on the process of transition, and the reasons for resistance to reform.

The capacity to change, or to absorb new technology, is also dependent on the available human capital and other resources in organizations (David 1997). For government organizations in Africa, weakened through decades of under-funding, and possibly corruption, the capacity for institutional change may be very low. Without substantial donor assistance, the fiscal reality may be that effective regulation will be difficult to achieve, given the low level of public revenues in most countries (even after the reorganization of spending priorities). 
Apart from historical studies (e.g. North and Weingast 1989; Greif 1995), our limited practical knowledge on institution-building stems from the recent economic transitions in Asia, Eastern Europe, the former Soviet Union and China (e.g. Clement and Murrell 1999). Some lessons have emerged toward achieving in the short run, at least a simple legal framework to protect property and contract rights.

This survey addresses first, the distinction between post-conflict and other developing countries, and discusses the additional challenges post-conflict countries may face in building and reforming institutions. Given some recent confusion in the literature of growth and institutions, a clear definition of the term 'institutions' according to the North framework (North 1990) and the likely origin of weak institutions is presented in section 3. Section 4 considers how institutions may be expected to have a linkage with growth, and summarizes a range of empirical evidence from cross-country studies, surveys and individual country analyses. The finding of a robust link would lend force to the need for institutional reform.

The remainder of the paper turns to the implementation of institutional reform, an issue scantily covered in the literature. Section 5 examines constraints to institutional reform, where the desired scope of the reform has to be traded-off against limited domestic resources and capacity; and it emphasizes the importance of domestic demand in gaining momentum for reform. Section 6 considers three important practical issues in implementing institutional reform. First, the idea that a partial reform may be achieved through the greater use of small claims courts and arbitration, and by enacting minimal, transparent rules, simple to apply and to monitor, rather than expensive fully-fledged new legal systems that cannot be effectively operated or monitored even in the medium term. This could facilitate the operation of markets in the short run, enhancing economic growth, and thereby, in a virtuous circle, generate further resources to proceed with deeper reforms. It also explores the wisdom of adopting and adapting to local circumstances, complex commercial and other codes from industrial countries. Finally, there is a consideration of the state's oversight (or monitoring) weaknesses when implementing new institutions. Section 7 concludes.

\section{Additional challenges faced by conflict and post-conflict countries}

Conflict seriously compounds the poor institutional legacy which post-conflict countries share with non-conflict, developing countries. The scale of institution-building required may be very different. Yet, conflict is not a uniform phenomenon; in Africa it ranges from destruction of the state itself (Somalia) to civil war in which central state structures remain intact (Angola and Mozambique) to inter-state war (the Eritrea-Ethiopia war of 1998-2000). Crucial, however, is the degree of institutional development achieved prior to conflict, as institutional memory can probably be resuscitated more easily than it can be created.

War affects the capacity and credibility of states to allocate, legislate and regulate toward growth, education and improved living standards. The state becomes impoverished, skilled civil servants may flee, and in some cases the state disappears completely (e.g. Mubarak 1997, on Somalia in the 1990s). In destroying infrastructure, public utilities and communications, war limits the effectiveness of institutions. War distorts and severely curtails formal private sector activity, as well as private regulatory 
institutions. As in Somalia, small-scale trade, agriculture and commerce may migrate to the informal sector, where private investment typically becomes opportunistic, smallscale and short-term in nature. Such activities will be promoted by social interaction and trust in communities, since informal rules can facilitate some types of economic contracts by minimizing moral hazard. In some cases social capital may recover during war itself, and take on new forms. Eritrea, for example, developed a high level of social capital in its 30-year war for independence from Ethiopia (Kibreab 2003). However, war may fragment communities and damage even these informal social mechanisms (e.g. in the 1990s, Rwanda and Sierra Leone, which experienced extensive cross-border migration).

Peace is often complicated by considerations of retributive justice (the expensive and time-consuming legal prosecutions of war criminals in Rwanda were almost fully funded by foreign aid). Lengthy operations in re-housing refugees and demobilization of soldiers compete for resources with institutional concerns (such as rewriting commercial law), and may cause protracted insecurity. The prevalence of guns can encourage entrenched criminality, as seen in South Africa and in Russia.

Conflict may itself create a need for new institutions. For example, the geographical and livelihood distributions of people may have altered as a result of conflict, as in sharply accelerated urbanization in Colombia and Angola. The pre-conflict institutional framework may therefore lack rules for the new dispensation. Perversely, the very weakness of institutions prior to conflict might make it harder to reverse any redistribution resulting from conflict. Thus, in Angola, even after the clearance of land mines, many will be unable to return to their former rural homes, as they will not be able to demonstrate their property rights.

A path-dependent view of institutional change thus suggests the sheer extent of loss of state and private capacity, state resources, and the informal capacity inherent in social networks, may substantially complicate reform and delay recovery. The obverse, however, is that poor institutional capacity leading to sub-standard management and accountability, and to weak and corrupted institutions, may induce renewed politicaleconomic tensions. Indeed, the recent empirical literature establishes such dual linkages between civil war and the quality of institutions (Collier 1998a, 1999; Easterly 2000). Further, post-conflict countries may face serious trade-offs when peace is elusive: beginning reform before a sustainable peace is assured, can constrain the possible routes for institutional change. But some institutional reform will certainly be necessary to secure peace.

\section{Defining institutions}

A recent review on the role of institutions in policy-making suggests that the considerable influence of North and his institutionalist school has mainly applied to political scientists and economic historians, rather than economists (Posen 1998). It is worth clarifying the definition of 'institutions'. Following North's school, the institutional framework is defined as a combination of both formal and informal constraints. In the absence of the state and of formal rules, a dense social network leads to the development of fairly stable informal structures. These customs, laws, trust and normative rules constitute an informal institutional framework for organizing activities. For instance, kinship ties are important for insurance, protection and law enforcement in 
tribal society (see Bates 1989). Naturally, informal constraints on behaviour remain pervasive and important in modern economies too (David 1994, 1997).

With economic development, the increasing specialization and division of labour associated with more complex societies raise the rate of return to formalizing rules. Formal rules include political and judicial rules, and economic rules and contracts, the function of which is to facilitate political or economic exchange. There is a hierarchy of such rules: from constitutions, to state and common laws, to specific by-laws, and finally to individual contracts. Usually the higher the rules lie in the hierarchy, the more costly they are to alter. Both the formal and the informal rules, and how effectively they are enforced, will define the incentives and wealth-maximizing opportunities of individuals and organizations.

Does conflict tend to damage more those rules higher up the institutional hierarchy? In some conflicts where there is a high level of destruction of the formal sector and of government organizations (e.g. Somalia), there is likely to be little remaining except those informal institutions that have persisted, and some newly-formed informal institutions. Institutional memory is very important, however, and where capacity allows it, formal rules can be more easily resurrected than if they had never existed. It would be interesting to examine the impact of different types of conflict at different points in hierarchy.

The term 'weak' institutions refers to the absence of useful formal and informal rules, to rules which have evolved to be sub-optimal, or to useful rules that are poorly enforced. North considers that costly information is the key factor. It is costly to measure the attributes of a good or service in economic exchange, but also to define and measure the rights that are transferred, and to protect these rights by policing and enforcing agreements. The more complex the exchange the more costly the institutions. High costs may prevent rules being devised so that ownership rights remain unclear (of course, changes in technology or relative prices may alter the relative gains from devising rules). Alternatively, useful rules may exist on paper, but they may not be enforced when the costs of monitoring and enforcement by the state prove too high, or when the state does not respect these rules.

Constitutions abound in Africa, but are ineffective in many cases. For example, the empirically observed lack of correlation between the constitutional autonomy of the central bank and low inflation in many developing countries (by contrast with industrial countries), has been partly attributed to the de facto weakness of the judiciary in enforcing autonomy (Cukierman et al. 1992). The judiciary may not be independent of political influence, while through poor funding and low capacity, it may also be slow and unpredictable. Similar caveats apply to the effective supervision and regulation of privatized financial intermediaries and utilities (e.g. Intriligator 1994). This has important social and economic ramifications. For instance, in Mozambique - and this is common to many African countries - commercial banks cannot rely on the judicial system to enforce contracts and recover bad debts; accordingly their lending rates include a large compensating premium (Addison et al. 2001).

Empirical measures of institutions show that there is a wide diversity in the perceived quality of legal and other institutions across countries. As Gray (1997b) emphasizes, the explanation for such differences is complex, and the legal processes are linked with the historical, political, cultural and economic environment. For instance, weak legitimacy 
of the law for former Soviet Union countries, and other transition countries in Eastern Europe, is partly related to the compromised position of legal institutions under communism. The same point applies to Africa's transition economies, for example Angola (Aguilar 2003). Poor institutional quality in many cases is significantly correlated with measures of prior political instability (e.g. Aron 2000: Table 2) —yet, weak institutions may be as much a cause as a result of underdevelopment and civil strife (see Addison 2003 on the interaction of conflict and underdevelopment in degrading institutions). Obviously more is needed than comparative quantitative data to distinguish cause from outcome, and even then, analysis may be speculative.

The role of inter-ethnic tensions in civil war has been emphasized by Collier (1998b). There are a number of possible links with weak institutions. For instance, when formal institutions are few, the concentration of economic activity within defined ethnic groups and limiting market exchange between them, may potentially create conflict where inter-ethnic relations are seen as a matter of predation rather than mutually profitable market exchange. Racial tensions of an institutional kind may also arise where there are few safeguards for minorities, and the judiciary, or the state in allocating resources, is seen to favour one group over another. In some instances, the source of conflict may not be the paucity of formal institutions, but the effect of a surfeit of ethnically-biased institutions in distributing resources only to particular groups (e.g. Apartheid South Africa).

\section{$4 \quad$ Institutions and growth}

How do weak institutions influence growth? Robust evidence for a causal linkage can lend force to the need for institutional reform, especially in post-conflict countries, where rapid growth is needed to overcome poverty and degradation. North (1990: 110) asserts:

Third world countries are poor because the institutional constraints define a set of payoffs to political/economic activity that do not encourage productive activity.

The institutional framework constrains the available choices and outcomes for individuals and organizations. North defines organizations to include political organizations (parties, senate, city council, regulatory agency, tribal councils), economic organizations (firms, trade unions, family farms, cooperatives, rotating credit groups), educational bodies (schools, universities, vocational training centres), and also social organizations (churches, clubs, civic associations).

When formal institutions are weak, this affects the size of both transactions costs and of transformation costs in the production process. Transformation costs are raised when individuals and firms faced with a risky environment prefer to employ low capital technology and operate with a short timehorizon, resulting in less efficient and competitive production. Transactions costs may be raised substantially through having to employ informal substitutes, often poor substitutes, for legally enforceable rights of property and contract. 
For instance, the reputational effects of repeated dealing and cultural homogeneity can facilitate the self-enforcement of contracts. Thus, economic exchange may be restricted to interpersonal exchange in small-scale production and local trade, in order to circumvent the contract enforcement problem. At one remove, it may allow impersonal contracts, enforced through family or kinship ties, and operating through social networks. There is a large applied literature examining how screening by reputation and ethnicity helps overcome moral hazard (e.g. Greif 1997). Instances are the dominance of altruistic relations in family-owned firms in Central and East Europe; or small-scale rotating credit schemes in developing countries, which rely on trust-based relationships and group pressure for enforcement (Besley 1995).

Practical examples from a range of countries suggest considerably raised transactions costs and curbs to business and trade, in the absent of formal mechanisms of guarantee. Costs may be raised if it proves time-consuming to search for a reliable contractual partner, while some firms pay intermediaries as go-betweens with unknown suppliers (e.g. traders in Ghana, Fafchamps 1996). Poor protection against theft may discourage stock accumulation, or require the costly protection of stock and payments of protection money to avoid ambush when transporting goods (e.g. grain market traders in Madagascar, Fafchamps and Minten 2001). Protection money may be paid to intermediaries where violence or the threat of it is used to enforce property and contract rights. Other direct costs include bribes paid to government intermediaries for licences. Obviously where illicit activities flourish, some of these costs are recouped, for instance, by avoiding formal sector taxes.

There are also several hidden costs. There may be barriers to new firms in certain markets in the absence of kinship ties or otherwise established reputations, which can constrain entrepreneurship and innovation, and reduce the size of the market (e.g. Gray 1997b on Bulgaria; Aguilar 2003 on Angola). Market competition may be reduced by mergers between firms toward greater vertical integration, transforming arms-length transactions into more easily monitored intra-firm transactions. The cumulative direct and hidden costs may be enormous (Posner 1998).

Most important, however, is the limit to the complexity of contracts that purely informal constraints can achieve. And in post-conflict countries, the collapse, partial or complete, of functioning state processes and the formal financial system during conflict must increase reliance on informal mechanisms. Avoidance of breach of contract may allow only the simplest of commercial processes (cash-and-carry: Fafchamps and Minten 2001). In industrial economies, formal rules guaranteeing long-term, multi-contract and multi-agent impersonal exchanges, characterize much of economic exchange. These types of complex, impersonal contracts are largely ruled out in the absence of effective third-party enforcement. Obviously, ethnic and cultural ties are pervasive in stimulating profitable business activity in strong economies too (e.g. in immigrant absorption into the US), but operate where more complex contracts are also available. Expressed differently, in undeveloped economies, a disproportionately large number of transactions will take place in spot (or contemporaneous) markets rather than by utilizing forward markets (Williamson 1995). Yet, the adoption of complex technology toward greater productivity in the growth process requires complex contracts. 


\subsection{Empirical evidence linking institutions and growth}

An informal attempt to establish a link between institutions and growth has used crosscountry surveys of foreign investors. Constraints to investment are ranked for a sample of countries, and include excessive bureaucracy, political instability, a volatile macroeconomic environment and lack of enforceable property rights. The World Bank has executed surveys in a broad range of countries (World Bank 1997 and 2002). These surveys find in general that the major deterrent to investment is political and economic policy uncertainty; other important factors include the lack of currency convertibility, poor infrastructure and regulation, rudimentary financial and business services, breach of contract and high taxation.

More rigorous economic analyses of growth and institutions employ various empirical indicators of institutions. Early work in this area includes Adelman and Morris (1967). Descriptions of the features of political and economic institutions - such as the presence or otherwise of statutory constitutional rights - say nothing about how well such institutions perform (e.g. whether such rights are effectively enforced). By contrast, measures of the quality of both formal and informal institutions are a measure of how effectively the existing institutional rules or norms are implemented.

Examples of quality measures of formal institutions include country business risk indicators based on the subjective rankings of different types of risk by a 'permanent' panel of experts, produced by private risk agencies and aimed at informing potential foreign investors. Unfortunately, these subjective measures of the quality of institutions may be highly influenced by recent measures of growth (see Haque et al. 1996), as well as by recent political events (Brewer and Rivoli 1990). Authors such as Knack and Keefer (1995) create an ordinal index by taking a simple average of four components of business risk: bureaucratic delay, nationalization potential, contract enforceability and infrastructure quality. The index is interpreted as a measure of security of contract and property rights (though clearly this abstracts from the relative importance, or weights, that investors place on the different components). Messick (1999) refers to similar measures as proxies for judicial system performance, which may be too broad an interpretation. The various indexes show strong correlations with growth and investment (that is, without implying any particular direction of causation).

For a recent survey and critique of such measures used in the growth literature, see Aron (2000). Related surveys include Alesina and Perotti (1994), Brunetti (1997), and Deaton and Miller (1996). Aron classifies the measures into five categories, as follows: (i) 'quality of institutions' measures (alternatively, measures of transactions costs), which capture the ease of doing business and respect of formal property rights (typically these are measures drawn from surveys or risk agencies); (ii) 'characteristics of political institutions' measures, including constitutional rights and descriptions of regime type (e.g. 'democracy') and duration; (iii) 'political instability' measures, including riots, strikes, civil war and changes in the executive; (iv) 'social capital' measures; and (v) 'social characteristics' measures, such as ethnic, cultural, historical and religious diversities.

In most cases, the institutional data on Africa are poor, particularly before 1985. There is little variation, with African institutions uniformly at the inefficient end of the crosscountry spectrum. Amongst African countries, post-conflict countries tend to have the highest risk ratings (see Aron 2000: Figures 2 and 3). Drawing policy conclusions from 
purely intra-African cross-country growth regressions with uniformly poor institutions is thus probably less useful than examining African case studies. For these reasons, generalized evidence from global cross-country growth and investment studies, with variation in institutional quality, potentially has important policy implications for Africa.

Evidence suggests first, that measures of the quality (or performance) of institutions appear to have a robust and significant indirect relationship with growth, via their effect on the volume of investment in separate investment equations (Mauro 1995). In the second place, there is also evidence, though it is weak, for a direct relationship between institutions and growth in Solow growth equations (Knack 1996; Knack and Keefer 1995; Barro 1996). When institutional quality proxies are included in growth regressions (alongside investment) they may be interpreted as improving the efficiency of investment. These results apply not only to quality measures of formal institutions, but also to informal institutions. Examples of the latter are Gastil's measures of civil rights, classified in Aron (2000) as promoting social capital (see, for example, Scully 1988; Kormendi and McGuire 1985; Isham et al. 1997); or measures of 'trust' and 'civic norms' (analysed in Knack and Keefer 1997).

However, it is important to highlight the simultaneous relationship between growth, investment and institutions, since causality may move in both directions. The majority of the studies in this tradition ignore these simultaneity issues and have other general methodological problems found in cross-country growth studies (see Temple 1999). Moreover, they often deal inadequately with endogenous institutional measures, while there are aggregation biases and other problems with the institutional measures used (Aron 2000). This makes a definite positive conclusion on the growth and institutional links difficult to pin down from the cross-country empirical evidence. The sometimes strong claims in this literature for causality should therefore be treated with caution; but the empirical results are nevertheless suggestive of a link between investment and institutions, as they are in single country studies.

\section{Constraints on institutional change}

Given the above caveats, the empirical growth and institutions literature probably supports: (i) legal and judicial institutions that promote market activity, e.g. protecting property rights and long-term multi-agent contracts; (ii) facilitating the development of social capital and observance of human rights; and (iii) transparent and accountable governance. It should be noted, however, that social capital remains a highly contested concept, and it is inadequately captured, and probably trivialized, by empirical measures such as 'newspaper readership' and 'membership of associations'. Studies employing objective measures of 'democracy' tend to find inconclusive results in growth regressions, and this result is discussed in Aron (2000), where the various trade-offs are explained. From a political science perspective, however, Friedman (1999) argues that Africa's specific circumstances make democracy a pre-requisite for growth.

Potentially this suggests a wide-ranging list of institutional reforms. Creating or altering laws is not sufficient. Well-designed laws may lie dormant without effective implementation and monitoring. An example is Russia where, despite modern law codes, entrenched criminality retards economic progress, and the administration of law 
by the judiciary and the police force is weak. Effective institutional reform requires the creation or restructuring of organizations which can implement the laws, state regulatory arrangements to oversee these organizations, and a facilitating environment for various private sector watchdog bodies. Africa's transition economies are far from having these most basic requirements.

\subsection{The scope of reform}

A capitalist rule-of-law ideal is described by Posner (1998). The judiciary is independent of political interference, judges and lawyers are competent and ethical, decrees are dependably enforced by competent court and other functionaries, delays are few and background rules and standards facilitate accurate decisions promoting commercial activity. This ideal often lies behind donor statements on institutional reform.

This is a far cry from the practical experience of most African countries. Yet, Posner argues that economic efficiency may not necessarily be seriously compromised even by wide departures from this ideal. He cites the economic success of China, despite a weak rule of law. Given fiscal and other constraints, he and others argue for a modest rules-based legal reform (see below). But even efficient rules may not be enforced and monitored by a weak administration, so that selected judicial and related reforms remain important.

Broadly, judicial reform concerns strengthening the judiciary in various ways, such as improving the selection, monitoring and discipline of judges; in-service training of judges; specific measures to increase independence of the judiciary; training of other legal professionals, creating bar associations and improving law schools; creating small claims courts and dispute resolution mechanisms; and providing resources and managerial training more rapidly to process cases (see Messick 1999). Legal reform encompasses revising or drafting commercial codes, bankruptcy statutes and corporate law, and improving the resources and management within a range of related government regulatory agencies, such as financial supervision and competition policy.

Constitutional provisions can potentially protect non-government organizations which may play an important watchdog role over the state and within the private sector, by producing and disseminating information (Gray 1997b). Examples are political parties and trades unions; and a range of private sector commercial and non-commercial groups and organizations, including a free private press and media association; accountants' and auditors' bodies; credit rating agencies; and professional associations, such as a bar associations.

Constitutional reform can stipulate a range of safeguards, such as protecting various rights of individuals and groups; limiting presidential terms; constraining changes in the electoral process; guaranteeing the independence of state auditors and the judiciary; guaranteeing independence of the central bank and sometimes stipulating policy rules; guaranteeing funding to a bureau of statistics to produce quality economic statistics; requiring court review of constitutionality of laws, and notice and hearing procedures before changes to the law (e.g. see Elster 1995). 
Finally, there are institutional reforms which streamline and make more transparent and accountable the way in which policy is made and implemented, or redefine the relationships of different government departments to one another, and of local government to central government. For instance, federal reform can alter the autonomy of provincial or local governments.

\subsection{The supply side: path dependence and fiscal constraints}

This broad set of reforms is clearly utopian in scope. However, even for a small subset of such reforms, it is questionable whether institutional change can be effected rapidly enough to create a virtuous circle and promote growth. Institutionalists expect profound changes in political, economic and social institutions to take a very long time to be adopted (North 1990). By analogy, European countries took many decades, if not centuries, to overcome major corruption, develop codes of commercial laws and have working justice.

Practically, what are the constraints on the effective reform of institutions? On the supply side, there are two key factors: the lack of malleability of institutions, and oftensevere factor and funding constraints. David (1994) adumbrates a path-dependent view of the evolution of institutions, with practical implications for institutional reform. Institutions are not very plastic or malleable. They are the products of their environments, and the negative impact of past distortions will long persist. According to David, organizational structures can become locked into narrow subsets of routines and goals. Change will tend to occur only incrementally, and possibly imperceptibly, where new functions are adapted to interlock with the pre-existing structure. The capacity to reform, say through the transfer of technical knowledge, may in practice be limited.

Many organizations in Africa are dominated by networks of the elite, who have 'sunk capital' into being able to operate in a weak institutional environment. Such organizations may perversely have become more efficient at making the society less productive, thus perpetuating and entrenching the weak environment (see David 1994). The World Bank (1997) cites the example of the legal profession in Peru opposing cost-cutting measures in land registration because it would allow other professionals to provide these services. It can prove very time-consuming to change rules with the wrong incentives from within such organizations.

It may seem tempting to discard poorly performing institutions and begin anew. Yet, where there are serious factor and funding shortages, it is undesirable to lose permanently even limited institutional expertise. Skills shortages constrain the creative process of designing laws, or adapting foreign laws to domestic circumstances; and the capacity to implement reforms. A tight budget further limits the resources for administrative effectiveness of organizations. Strong fiscal constraints argue for reform of existing institutional arrangements, simplifying laws and reducing inefficiencies. For many post-conflict countries, however, there may be little left in the way of state institutions and organizations to guarantee property and other rights. Eritrea, at least in the period from its independence in 1993 up to the start of the war with Ethiopia in 1998 , is one exception.

Difficult trade-offs are implied by a reallocation of priorities to maximize the use of existing resources. These trade-offs may be complex to evaluate when expenditure takes 
years to come to fruition (e.g. expenditure on education, and improving law schools). Some ideas might appear quite radical in view of the competing demands for limited funds. Emphasizing the absence of skills to implement reform, Haque and Aziz (1999) argue for changed incentives in public sector employment policies: for instance, paying civil servants substantially more to retain skilled personnel, or to reverse human capital flight (see also Murphy et al. 1991).

Foreign aid and technical assistance have to a degree relaxed the budget constraint in institutional reform (although ironically, Alesina and Weder (1999) find that on some measures of corruption, more aid has gone to the more corrupt countries). The value of aid-funded reform depends on its sustainability when aid is eventually withdrawn. In theory, reform might eventually be sustainable, despite the increased call on government recurrent expenditures, in view of reduced numbers of motivated civil servants reaping efficiency gains. However, examples show a poor record more often than not.

\subsection{The demand for institutional reform}

Given a supply of market-friendly laws, and adequate organizations to implement and enforce them, Gray (1997a, 1997b) emphasizes the importance of the demand for these laws from market participants. In her view, institutional reform is not a prerequisite for economic change, but is inextricably linked with it. Credible reform depends on minimizing state actions that undermine the demand for the new institutions. Gray (1997c) gives an example where bailouts of Hungarian banks by the state during 1991-94, served to decrease the incentives of these banks to use new collateral and bankruptcy laws for their debt collection. Entrenching institutions with users can be facilitated by encouraging their wide usage. An example is the decision in South Africa, when writing its first constitution in 1996, to allow ordinary courts to try constitutional cases (although the government may be restrained by an independent constitutional court, appointed by independent selectors). This has encouraged a broad familiarity with the constitution, and entrenched it with the whole judiciary as well as the populace. It is also important to disseminate information to users about new laws and rights.

While successful law enforcement and dispute resolution can be self-reinforcing, poor signals from inadequate laws with inconsistencies and economic flaws will deepen public mistrust of law. By the same token, there are serious costs in delaying concerted reforms, of lost opportunity and distortions. For example, in the vacuum left by the absence of effective legal enforcement, illegal enforcement may rapidly substitute for it (commonplace in the former Soviet Union), and corruption and organized crime become entrenched and hard to eradicate (see also Gambetta 1993 and Varese 2001).

\section{Some practical issues in institutional reform}

A wholesale legal reform to protect property, contract and human rights would involve expensive inputs of educated labour, for instance in the judiciary and other aspects of legal practice. This paper suggests that utopian policy prescriptions for institutional reform, so prevalent in the literature, should instead take cognisance of practical constraints in implementation. Several possible practical lessons to this end are 
discussed. However, for those post-conflict countries with little left in the way of either formal or informal mechanisms (e.g. in Africa, Somalia and Sierra Leone), rather than incremental change, a quantum leap may be required to produce even a modest, functioning legal market framework. Moreover, there may be complex interaction effects, so that concerted institutional reforms enacted together, may be more effective than piecemeal reforms.

\subsection{The 'rules-first' strategy}

In African economies, resuscitating human capital on the scale required for a wholesale legal reform is likely to take many years. Posner (1998) endorses the idea of more rapid reform, by enacting efficient rules to be administered by less-than-efficient organizations, rather than expensive and time-consuming reform to the organizations themselves (see Hay et al. 1996). He argues that a fairly modest fiscal expenditure may secure a partial law reform, which could facilitate the operation of markets and enhance economic growth, and thereby, in a virtuous circle, generate further resources to proceed with deeper reforms. Moreover, such reform is comparatively inexpensive to design, implement and monitor, and also to disseminate.

Posner emphasizes that such rules applying to commercial property and contract should be both substantively and procedurally efficient. They should both promote the efficient allocation of resources, and reduce the cost or increase the accuracy of the legal system. An example of the former is a rule requiring consent for use of another's property; and of the latter, a rule that requires legally binding contracts to be in writing. He gives other examples of procedurally efficient rules, which reduce the costs of information and delays in implementation: prescribing a time limit within which to file legal claims; use of alternative methods of dispute resolution; and paying interest from the date of filing the claim to the winner of a damages claim.

The idea, therefore, is to match capacity to reform in the short-term, and in due course, to move away from simple rules. Posner suggests that on balance the choice of 'rules' over 'standards' favours improved judgement, particularly for judiciaries with limited capacity. The violation of a rule is relatively straightforward to decide. By contrast, the administration of 'standards' requires discretion: for instance, 'negligence' or 'bad faith'. However, it should be noted that in some circumstances, standards are easier to understand or less arbitrary than simplistic rules.

By reducing the element of judicial discretion, rules can also be made more transparent and easier to monitor, both by the state and the public. In general, asymmetry of information is a source of costly failure in monitoring by under-staffed and underskilled government agencies. Incentive mechanisms can be devised to improve monitoring, such as judges sitting in panels to reduce the possibility of bribery and corruption (probably of limited use where judicial capacity is low); and linking pension rights to the competence and honesty of judges (Posner 1998).

The piecemeal approach is not without trade-offs. First, reforms are more easily initiated in the first blush of reformist zeal under a new leadership: gradualism can fall prey to a loss of momentum in reform. Secondly, a sophisticated legal reform is needed to fully protect human rights: yet, many commentators believe such rights are inextricably linked with economic outcomes (e.g. Drèze and Sen 1995). For post- 
conflict societies, the abuse of minority rights and ethnic conflict may perpetuate instability (as in Liberia, in recent years). Somewhat controversially, Posner (1998) points to a trade-off between strict criminal laws and basic human rights, and suggests that under rampant crime (e.g., Russia), de-emphasis on the protection of civil liberties may actually facilitate the protection of property and contract rights. On the other hand, fewer constraints on underpaid and corrupt police forces, apart from exacerbating human rights abuses, may simply render policing more ineffective.

\subsection{Transplanting foreign law with domestic participation versus home-grown law}

In many countries, the formal legal system resulted from codifying informal enforcement mechanisms, when returns to formalizing laws became high enough. Users of the laws often catalysed change, due to the inconvenience or high costs of operating without a formal framework (e.g. see Milgrom et al. 1990). Hybrid systems may appear: in South Africa and Rwanda, for example, customary courts are formally charged with responsibility for certain types of dispute. The implied pace of change might be too slow, however, to meet the institutional demands of economic agents in sophisticated markets. Some countries have experienced extreme political and economic regime changes. The pre-communist legal heritage of many Central and East European countries predates the First World War; while informal market institutions may have been suppressed for decades.

Some argue that while it may be possible for reform to take hold, it will only be sustainable if it builds slowly on existing informal mechanisms (Cooter 1997). By contrast with this bleak view, various international organizations and governments continue to expend huge resources on institutional reform in transition and developing countries. For instance, apart from training expenditure on legal practitioners and judges, USAID has spent significant funds in Africa promoting alternative dispute resolution such as small claims courts and arbitration (e.g. see USAID annual agency performance reports). For a review of several evaluations of judicial reform in USAIDsponsored programmes, see Messick 1999: 124-5.

While not entirely sanguine about the prospects for reform, researchers from reformminded institutions such as the World Bank criticize the views of Cooter (1997), and more generally the notion that institutional reform is bound to end in failure (e.g. Gray 1997a). Experience of reforming commercial codes in Eastern Europe leads Gray to the view that even when newly-supplied law reform does not take hold, at the least, it triggers the process of institutional reform and debate about reform. Similarly, Elster (1995) argues that written constitutions provide a benchmark, even when they are not enforced.

While sustainable reforms require that the institutional changes are appropriate to the local context and culture, 'reinventing the wheel' may not be desirable under the severe resources constraints often faced by developing and especially post-conflict countries. Large, complex bodies of legal codes already exist from market economies, which could be adapted locally. Posner (1998) points out that certain areas of the law might be more easily transplanted: for instance, commercial law versus constitutional law. The tradition of adopting foreign law codes has been tried and tested historically; for instance, in Turkey in the 1920s, Ataturk closely adapted the Italian penal code, Swiss 
civil code and German commercial code. Adoption of foreign codes has often been found wanting; for instance, see a critique of the 'Law and Development' movement of the 1960s, in Messick 1999: 125-8.

Experience suggests the importation of foreign law should draw heavily on local expertise; and in drafting local law, take into account customary law and informal constraints. Ideally, where the technical skills are available, a local law commission could modernize national laws through adapting foreign law (Posner 1998; Gray 1997b). The legal literature contains lengthy debates on transplanted law and the fitting of rule or discretion to low and high trust environments. For instance, US contract law is highly discretionary in order to inject trust into atomistic relations, while English contract law is rule-based and rejects discretion, assuming a high level of trust and selfenforcement in the market.

The local adaptation of foreign laws can aim to facilitate implementation and enforcement, to ameliorate the effects of a weak institutional environment. In line with the 'rules-first' approach, Posner suggests requiring more contracts to be in writing, that discretionary aspects of imported law be minimized through modifying or deleting 'standards', and extending codes to include contracts elsewhere decided under the common law (e.g. insurance contracts in the US). Many Central and East European countries have transplanted commercial legislation, in whole or in part, from advanced market economies. Gray (1997b) refers to Russian company law, adopted late 1995, which incorporates provisions to enhance protection of minority shareholders against dominant insiders. More types of decisions require shareholder approval; while decisions on mergers or sales of assets require a supermajority approval (Black et al. 1996). Further, markets in many less developed countries are thin and subject to frequent shocks. In devising formal contracts, some flexibility could be accommodated, as found in many informal contracts in these circumstances (Fafchamps 1996).

In all countries there is a mix of formal and informal mechanisms of enforcement. In industrial countries with highly developed and efficient commercial legislation, the majority of less complex disputes are probably solved by negotiation given the high costs of litigation (Posner 1998). Similarly, Gray (1997b) suggests that the best formal legal systems operate only at the margin, while compliance with laws or selfenforcement is carried out by society. But arguably, it is the threat of an effective legal means of settling disputes that encourages these informal channels to function smoothly. And unfortunately in many developing countries, the culture has evolved to produce minimal voluntary compliance with the law.

\subsection{The oversight role of international and domestic external agents}

It is often stressed that sustainable reform depends on the political will of governments. When the momentum for reform and enforcing reforms depends on the whims and standards of leaders (e.g. the positive contrast of Eritrea or secessionist Somaliland against Zimbabwe in the 1990s), this introduces arbitrariness and risk to reform, significantly adding to the costs.

Assuming that reforms are designed to promote rules, decrease state discretion and increase transparency, the taxing question remains: 'who guards the guards' during implementation of reforms. Under highly asymmetric information and with limited state 
resources for constraining abuses via judicial or administrative bodies, there is likely to be negligible monitoring and accountability of the state (see Aron 1996). There may be some debate and criticism from parliamentary committees. But typically these committees are under-resourced and have no formal mandate to act. The problems are worsened in areas of technical complexity. Unfortunate examples include the negative income and wealth distributional consequences of the privatization of state enterprise assets in Russia, and of the investment fund pyramid schemes in Albania.

The state oversight problem has resulted in an increasing emphasis by aid-giving entities in promoting the role of 'external agencies of restraint' (see Collier 1996). These comprise international organizations of various types; domestic private sector organizations; and groups in civil society. These agencies cannot solve the oversight problem, but can help embed a culture of greater transparency and accountability. For instance, a range of private sector watchdog bodies complements the role of the state judicial system by providing standards and information (e.g. auditing, accountancy, credit bureaux and an independent press). Some may be subsidiaries of international companies, and uphold international standards. International groups can also help oversee electoral processes.

A state that abuses rights and undermines the courts and freedom of the press, will see a costly decrease in its ability to integrate globally. International credit-rating agencies discourage linkages through trade, capital and technology flows, with risky countries. It is notable that until the mid-1990s, the World Bank, constrained by its Articles of Agreement, was reluctant to challenge political mismanagement through conditional aid or withdrawal of aid. This situation has altered in practice since the late 1990s, with an emphasis on good governance in the provision of aid (for an overview, see Burnside and Dollar 2000). The effect of aid withdrawal can be dramatic, as provision of much private and public foreign credit relies on the sanction of multilateral agencies. There may also be explicit sanctions on renegade countries by the Commonwealth, United Nations or other international groupings. These have exacerbated the pressures on Apartheid South Africa, and more recently on Nigeria and Zimbabwe. Internationally observed measures have lately aimed to discourage civil war, including controls on the export of arms to warring aid-recipients. International pressure has induced the company De Beers, the main marketing agent of diamonds, to change its standards of marketing and exclude diamonds originating from rebel-held areas in several countries experiencing conflict. Amnesty International reports induce international opprobrium for the abuse of rights, and may influence countries hopeful of greater foreign integration (e.g. Turkey).

Authors such as Putnam (1993) dispute the notion that social capital can be created or even encouraged. However, much foreign aid is now directed at strengthening the formation of non-governmental groups and networks, and the voice of civil society. Donors stress the role of a free press, human rights, the role of women and enhancing information. International political 'conditionality' is probably most effective when used in support of democratic opposition from within the relevant country, and helps deal with the charge of 'imperialism' since it is then a response to local demand. International efforts helped sustain the independent media in Zimbabwe in 2000 and 2001, despite assassination attempts, the torture of journalists and destruction of the printing press. 


\section{Conclusion}

Institutions are altered by conflict, depending on the scale, duration and type of war. At one extreme, formal political, social and economic institutions may be completely destroyed (e.g. Somalia), while the importance and type of informal institutions may be changed. Hysteresis is important: institutional memory may be more easily resuscitated than created, so countries with previously effective formal institutions may be better off. Yet, while the scale of institution-building may be very different, post-conflict countries share with other developing countries similar challenges in institutional reform. Wellfunctioning institutions may promote development, but they are at least as much the outcome of other processes of development. North's approach fully recognizes this dual causation, but encourages particular sets of institutional reforms as a prerequisite to lowering transaction and transformation costs of production to promote economic activity-and there is some empirical support for the effect of different types of institutions on promoting growth. Until comparatively recently, economists have regarded organizations as highly malleable and able to respond rapidly to such changed institutional incentives. But in practice, the capacity to reform from within existing organizations may be very limited, while there may be significant resistance to reform. In the institutionalists' view, this is a very slow process indeed.

While a great deal has been written about the desirability of wide-ranging institutional reform, there remain unresolved questions about practically achieving effective institution-building in capacity-constrained developing countries. The desired scope of sustainable reform has to be traded-off against limited domestic resources. While fiscal resources may be supplemented by foreign aid, it is far harder to reverse sharply depleted capacity in post-conflict countries. The most useful lessons from this survey specifically address the question of capacity constraints.

Empirical evidence, including from investor-based surveys, suggests well-functioning contract law and property rights promote more complex types of exchange, common in more developed economies. Law reform can be matched to capacity in the short run by enacting minimal, transparent rules, simple to apply and to monitor, rather than expensive fully-fledged new legal systems that cannot be effectively operated or monitored even in the medium term. The development and greater use of alternative dispute mechanisms, such as small claims courts and arbitration, can also facilitate a range of transactions. In time there may be fiscal benefits from increased market capacity that can provide the resources for deeper reforms. Under resource constraints, more complex law codes can evolve by importation of tried and tested foreign law, but practical experience suggests that to be acceptable, these laws should be carefully adapted using local expertise and take into account local customary law and informal constraints where possible. Credible reform also depends on minimizing state actions that undermine the demand for the new laws from market participants and citizens.

With the large number of formal and informal political, economic and social institutions particular to different countries, there are complex interactive effects, and important sequencing issues arise. For instance, tackling judicial reform in a hostile political context might prove largely irrelevant for improving market activity and observance of human rights. Even a relatively independent judiciary in Zimbabwe was heavily undermined by a police state in 2002. International agencies of restraint have a limited role to play but are ultimately no substitute for an active citizenry. Thus, the accountability of the State to its citizens can emerge as a pre-condition for the 
effectiveness of other types of institutional reform. In economic terms, the resulting protection from arbitrary state actions reduces the uncertainty facing investors and traders who commit resources when returns accrue only in the future.

\section{References}

Addison, T. (2003). 'Communities, Private Sectors, and States', in T. Addison (ed.) From Conflict to Recovery in Africa. Oxford: Oxford University Press.

Addison, T., Alemayehu Geda, Philippe Le Billon, and S. Mansoob Murshed (2001). 'Financial Reconstruction in Conflict and "Post-Conflict" Economies'. WIDER Discussion Paper No. DP2001/90. Helsinki: UNU/WIDER.

Adelman, Irma, and Cynthia Morris (1967). Society, Politics and Economic Development: a Quantitative Approach. Baltimore: Johns Hopkins University Press.

Aguilar, R. (2003). 'Angola's Incomplete Transition', in T. Addison (ed.), From Conflict to Recovery in Africa. Oxford: Oxford University Press.

Alesina, Alberto, and Roberto Perotti (1994). 'The Political Economy of Growth: A Critical Survey of the Recent Literature'. The World Bank Economic Review 8 (3): 351-371.

Alesina, Alberto, and Beatrice Weder (1999). 'Do Corrupt Governments Receive Less Foreign Aid?' NBER Working Paper No. 7108. Cambridge, MA: National Bureau of Economic Research.

Aron, Janine (1996). 'The Institutional Foundations of Growth', in Stephen Ellis (ed.), 'Africa Now: People, Policies and Institutions'. London: James Currey/Heinemann and Paris: Karthala.

Aron, Janine (2000). ' Growth and Institutions: A Review of the Evidence'. World Bank Research Observer, 15 (1): 99-135.

Barro, Robert J. (1996). 'Democracy and Growth'. Journal of Economic Growth 1 (1): $1-27$.

Bates, Robert (1989). Beyond the Miracle of the Market: The Political Economy of Agrarian Development in Rural Kenya. Cambridge: Cambridge University Press.

Besley, Timothy (1995). 'Non-market Institutions for Credit and Risk Sharing in Lowincome Countries'. Journal of Economic Perspectives 9: 115-127.

Black, Bernard et al. (1996). 'Corporate Law from Scratch', in R. Frydman, C. Gray and A. Rapaczynski (eds), Corporate Governance in Central Europe and Russia, Vol. 2. Budapest: Central European University Press.

Brewer, Thomas, and Pietra Rivoli (1990). 'Politics and Perceived Country Creditworthiness in International Banking'. Journal of Money, Credit and Banking 22 (3): 357-69.

Brunetti, Aymo (1997). 'Political Variables in Cross-Country Analysis'. Journal of Economic Surveys, 11 (2): 163-90. 
Burnside, C., and D. Dollar (2000). 'Aid, Growth, the Incentive Regime and Poverty Reduction', in C. L. Gilbert and D. Vines (eds), The World Bank: Structure and Policies. Cambridge, Cambridge University Press.

Clement, Cynthia, and Peter Murrell (1999). 'Assessing the Value of Law in the Economic Transition from Socialism: An Introduction', in Peter Murrell (ed.), Assessing the Value of Law in the Economic Transition from Socialism. College Park: IRIS (Center on Institutional Reform and the Informal Sector), University of Maryland.

Collier, Paul (1996). 'The Role of the African State in Building Agencies of Restraint', in M. Lundahl and B. Ndulu (eds), New Directions in Development Economics: Growth, Environmental Concerns and Government in the 1990s. Studies in Development Economics, vol. 3. London and New York: Routledge, 282-98.

Collier, Paul (1998a). 'On Economic Causes of Civil War'. Oxford Economic Papers, 50 (4): 563-73.

Collier, Paul (1998b). 'The Political Economy of Ethnicity'. WPS-98-8. Washington, DC: World Bank.

Collier, Paul (1999). 'On the Economic Consequences of Civil War'. Oxford Economic Papers, 51: 168-83.

Collier, Paul, and Jan Gunning (1999). 'Explaining African Economic Performance'. Journal of Economic Literature, 37 (1): 64-111.

Cooter, Robert (1997). 'The Rule of State Law and the Rule-of-Law State: Economic Analysis of the Economic Foundations of Development', in Proceedings of the World Bank Annual Conference on Development Economics 1996. Washington, DC: World Bank, 189-217.

Cukierman, A., S. Webb, and B. Negapti (1992). 'Measuring the Independence of Central Banks and its Effect on Policy Outcomes'. World Bank Economic Review, 6: 353-98.

David, Paul (1994). 'Why Are Institutions the 'Carriers of History? Path Dependence and the Evolution of Conventions, Organizations and Institutions'. Structural Change and Economic Dynamics, 5 (2): 205-220.

David, Paul (1997). 'Rethinking Technology Transfers: Incentives, Institutions and Knowledge-Based Industrial Development', in Charles Feinstein and Christopher Howe (eds), Chinese Technology Transfer in the 1990s: Current Experience, Historical Problems and International Perspectives. Cheltenham: Edward Elgar.

Deaton, A., and R. Miller (1996). 'International Commodity prices, Macroeconomic Performance and Politics in Sub-Saharan Africa'. Supplement, Journal of African Economies, 5 (3): 'AERC Plenary Sessions 1994-95', 99-191.

Drèze, Jean, and Amartya Sen (1995). India: Economic Development and Social Opportunity. New Delhi: Oxford University Press.

De Vanassy, X., and Z. Spindler (1992). 'Freedom and Growth: Do Constitutions Matter?' Vancouver: Simon Fraser University. Mimeo. 
Easterly, William (2000). 'Can Institutions Resolve Ethnic Conflict?' Working Paper 2482. Washington, DC: World Bank.

Easterly, William, and Ross Levine (1997). 'Africa's Growth Tragedy: Policies and Ethnic Divisions'. Quarterly Journal of Economics, CXII (4): 1203-250.

Elster, Jon (1995). 'The Impact of Constitutions on Economic Performance', in Proceedings of the World Bank Annual Conference on Development Economics 1994. Washington, DC: World Bank, 209-226.

Fafchamps, Marcel (1996). 'The Enforcement of Commercial Contracts in Ghana'. World Development, 24 (3): 427-48.

Fafchamps, M., and B. Minten (2001). 'Property Rights in a Flea Market Economy'. Economic Development and Cultural Change, 49 (2): 229-67.

Friedman, Steven (1999). 'Agreeing to Differ: African Democracy-Its Obstacles and Pitfalls'. Social Research, 66 (3): 825-58.

Gambetta, Diego (ed.) (1988). Trust: Making and Breaking Cooperative Relations. Oxford and New York: Blackwell.

Gambetta, Diego (1993). The Sicilian Mafia: The Business of Private Protection. Cambridge, MA and London: Harvard University Press.

Gray, Cheryl (1991). 'The Legal Process and Economic Development: A Case Study of Indonesia'. World Development, 19 (7): 763-78.

Gray, Cheryl (1997a). 'Comment on Cooter', in Proceedings of the World Bank Annual Conference on Development Economics 1996. Washington, DC: World Bank, 218221.

Gray, Cheryl (1997b). 'Reforming Legal Systems in Developing and Transition Economies'. Finance and Development, 94 (3).

Gray, Cheryl (1997c). 'Creditors' Crucial Role in Corporate Governance'. Finance and Development, June.

Greif, Avner (1995). 'Markets and Legal Systems: the Development of Markets in Late Medieval Europe and the Transition from Community Responsibility to Individual Legal Doctrine'. IRIS Working Paper Series: 159, 1-34.

Greif, Avner (1997). 'Contracting, Enforcement and Efficiency: Economics beyond the Law', in Proceedings of the World Bank Annual Conference on Development Economics 1996. Washington, DC: World Bank, 239-265.

Haque, Nadeem U1, and Hahangir Aziz (1999). 'The Quality of Governance: "SecondGeneration" Civil Service Reform in Africa'. Journal of African Economies, 8 Supplement 1: 68-106.

Haque, Nadeem U1, Manmohan S. Kumar, Nelson Mark, and Donald J. Mathieson (1996). 'The Economic Content of Indicators of Developing Country Creditworthiness'. IMF Working Paper 96/9. Washington, DC: IMF.

Hay, Jonathan, Andrei Schleifer, and Robert W. Vishny (1996). 'Privatization in Transition Economies: Towards a Theory of Legal Reform'. European Economic Review, 40 (315): 559-68. 
Intriligator, Michael D. (1994). 'Privatization in Russia Has Led to Criminalization'. Australian Economic Review, 105 (April-June): 4-14.

Isham, Jonathan, Daniel Kaufmann, and Lant Pritchett (1997). 'Civil Liberties, Democracy, and the Performance of Government Projects'. World Bank Economic Review, 11 (2): 219-42.

Kibreab, G. (2003). 'Displaced Communities and the Reconstruction of Livelihoods in Eritrea', in T. Addison (ed.), From Conflict to Recovery in Africa. Oxford: Oxford University Press.

Kiguel, Miguel, J. Saul Lizondo, and Stephen O'Connell (eds) (1997). Parallel Exchange Rates in Developing Countries. London: Macmillan and New York: St. Martin's.

Knack, Stephen (1996). 'Institutions and the Convergence Hypothesis: The CrossNational Evidence'. Public Choice, 87 (3-4): 207-28.

Knack, Stephen, and Philip Keefer (1995). 'Institutions and Economic Performance: Cross-Country Tests using Alternative Institutional Measures'. Economics and Politics, 7 (3): 207-27.

Knack, Stephen, and Philip Keefer (1997). 'Does Social Capital Have an Economic Payoff? A Cross-Country Investigation'. Quarterly Journal of Economics, CXII (4): 1251-88.

Kormendi, Roger C., and Philip G. McGuire (1985). 'Macroeconomic Determinants of Growth: Cross-country evidence'. Journal of Monetary Economics, 16: 141-63.

Mauro, Paolo (1995). 'Corruption and Growth'. The Quarterly Journal of Economics, CX (3): 681-712.

Mankiw, N. Gregory, David Romer, and David N. Weil (1992). 'A Contribution to the Empirics of Economic Growth'. The Quarterly Journal of Economics, 107 (2): 40737.

Messick, Richard (1999). 'Judicial Reform and Economic Development: A Survey of the Issues'. World Bank Research Observer, 14 (1): 117-36.

Milgrom, Paul, Douglass North, and Barry Weingast (1990). 'The Role of Institutions in the Revival of Trade: the Law of Merchants, Private Judges, and the Champagne Fairs'. Economics and Politics, 2: 1-23.

Mubarak, J. (1997). "The "Hidden Hand" behind the Resilience of the Stateless Economy of Somalia'. World Development, 25 (12): 2027-41.

Murphy, Kevin, Andrei Schleifer, and Robert W. Vishny (1991). 'The Allocation of Talent: Implications for Growth'. The Quarterly Journal of Economics, May: 50330 .

North, Douglass (1990). Institutions, Institutional Change and Economic Performance. Cambridge: Cambridge University Press.

North, Douglass (1997). 'The Contribution of the New Institutional Economics to an Understanding of the Transition Problem'. WIDER Annual Lectures 1. Helsinki: UNU/WIDER. 
North, Douglass, and Barry Weingast (1989). 'Constitutions and Commitment: the Evolution of Institutions Governing Public Choice in Seventeenth-Century England'. Journal of Economic History, 49 (4): 803-32.

Posen, Adam (1998). 'Do Better Institutions make Better Policy?' International Finance, 1 (1): 173-205.

Posner, Richard (1998). 'Creating a Legal Framework for Economic Development'. World Bank Research Observer, 13 (1): 1-11.

Putnam, Robert D. (1993). Making Democracy Work: Civic Traditions in Modern Italy. Princeton, NJ: Princeton University Press.

Scully, Gerald W. (1988). 'The Institutional Framework and Economic Development'. Journal of Political Economy, 96 (3): 652-62.

Shleifer, Andrei (1995). 'Establishing Property Rights' in Proceedings of the World Bank Annual Conference on Development Economics 1994. Washington, DC: World Bank, 93-117.

Solow, Robert M. (1956). 'A Contribution to the Theory of Economic Growth'. Quarterly Journal of Economics, LXX: 65-94.

Stiglitz, Joseph (1986). 'The New Development Economics'. World Development, 14 (2) Special Issue: 257-65.

Stiglitz, Joseph (1994). 'The Role of the State in Financial Markets', in Proceedings of the World Bank Annual Conference on Development Economics 1993. Washington, DC: World Bank.

Stiglitz, Joseph (1998). 'More Instruments and Broader Goals: Moving towards the Post-Washington Consensus'. WIDER Annual Lectures 2. Helsinki: UNU/WIDER.

Temple, Jonathan (1999). 'The New Growth Evidence'. Journal of Economic Literature, 37 (1): 112-56.

Varese, F. (2001). The Russian Mafia: Private Protection in a New Market Economy. Oxford: Oxford University Press.

Williamson, Oliver (1995). 'The Institutions and Governance of Economic Development and Reform', in Proceedings of the World Bank Annual Conference on Development Economics 1994. Washington, DC: World Bank, 171-97.

Woolcock, Michael, and Deepa Narayan (2000). 'Social Capital: Implications for Development Theory, Research and Policy'. World Bank Research Observer, 15 (2): 225-49.

World Bank (1994). Governance: The World Bank's Experience. Washington, DC: World Bank.

World Bank (1997). The State in a Changing World. World Development Report. New York: Oxford University Press.

World Bank (2002). Building Institutions for Markets. World Development Report. New York: Oxford University Press. 